\title{
Influence of diet and feeding strategy on the performance of nitrifying trickling filter, oxygen consumption and ammonia excretion of gilthead sea bream (Sparus aurata) raised in recirculating aquaculture systems
}

\author{
Sergio Godoy-Olmos ${ }^{1} \cdot$ Ignacio Jauralde $^{1}$ (i) $\cdot$ Raquel Monge-Ortiz $^{1}$. \\ María C. Milián-Sorribes ${ }^{1} \cdot$ Miguel Jover-Cerdá $^{1} \cdot$ Ana Tomás-Vidal $^{1}$. \\ Silvia Martínez-Llorens ${ }^{1}$
}

Received: 6 May 2021 / Accepted: 16 December 2021 / Published online: 4 January 2022

(C) The Author(s) 2022

\begin{abstract}
Gilthead sea bream (Sparus aurata) was raised in six individual recirculating aquaculture systems (RAS) whose biofilters' performance was analyzed. Fish were fed with three different diets (a control diet, a fishmeal-based diet (FM), and a plant meal-based diet $(\mathrm{VM})$ ) and with three different feeding strategies (manual feeding to apparent satiation, automatic feeding with restricted ration, and auto-demand feeding). For every combination of diet and feeding strategy, the mean oxygen consumption, ammonia excretion, and ammonia removal rate were determined. Fish fed with the VM diet consumed the most oxygen $\left(20.06 \pm 1.80 \mathrm{gO}_{2}\right.$ consumed $\mathrm{kg}^{-1}$ day $\left.^{-1}\right)$. There were significant differences in ammonia excretion depending on the protein content and protein efficiency of the diet, as well as depending on feeding strategy, which in turn affected ammonia removal rates. Fish fed by auto-demand feeders led to the highest mean ammonia removal rate $(0.10 \mathrm{gN}$-TAN removed $\mathrm{m}^{-2}$ biofiltration area day ${ }^{-1}$ ), while not leading to peaks of high ammonia concentration in water, which preserve fish welfare and growth.
\end{abstract}

Keywords Recirculating aquaculture systems · Trickling filter · Oxygen consumption · Ammonia excretion $\cdot$ Feeding strategy $\cdot$ Sparus aurata

\section{Introduction}

In recirculating aquaculture systems (RAS), in which the hydraulic residence time is as large as possible, ammonia is usually removed by nitrifying biofilters, adopted from wastewater treatment (Liao and Mayo 1972). Ammonia concentration in aquaculture

Handling editor: Pierre Boudry

Ignacio Jauralde

igjaugar@upvnet.upv.es

1 Aquaculture and Biodiversity Group, Universitat Politècnica de València, C/Camino de Vera s/n, 46022 Valencia, Spain 
systems is quite lower than in wastewater, but low concentrations of ammonia are still toxic to fish. Colt (2006) recommended $0.025 \mathrm{mgL}^{-1}$ as the highest acceptable threshold). Complete elimination of ammonia in RAS is challenging as nitrifying biofilters are known to be less efficient in low ammonia concentration conditions (Piedrahita 2003). Another condition which impacts biofilter efficiency (Eding et al. 2006; Foss et al. 2009) is the variability in the influent ammonia, which is relative to the excretion patterns of the fish, heavily dependent on feeding (Echevarría et al. 1993; Dosdat et al. 1996; Leung et al. 1999).

Because of this, the objective to improve biofilter performance for aquaculture has led to a series of meticulous studies. Several factors that affect nitrification performance include reactor-specific parameters (filter media, hydraulic loading) as well as water quality parameters such as temperature, influent ammonia concentration, $\mathrm{pH}$, or organic matter (Eding et al. 2006). The effect of these factors on nitrification rate has been investigated by several authors, with or without including live fish on their experiments (Zhu and Chen 1999; Godoy-Olmos et al. 2016, 2019). Ammonia load is probably the process parameter that affects the most ammonia removal rate. Several authors have stated 1/2-order substrate-dependent kinetics (Salvetti et al. 2006; Díaz et al. 2012; von Ahnen et al. 2015), and whereas the quantification of the effects of other parameters has been reported as well, their effect is somewhat less influential (Lyssenko and Wheaton 2006).

In aquaculture farming situations, the ammonia excretion is dependent on species (Dosdat et al. 1996), biomass (Wagner et al. 1995), feed intake (Leung et al. 1999), protein content of the diet (Cheng et al. 2003), and feeding regime (Wu and Gatlin 2014). Studies on biofilter performance carried out using fish (von Ahnen et al. 2015; Gallego-Alarcón and García-Pulido 2017) usually use commercial diets and feeding strategies based on fixed rations. Few studies use diets with partial or total fishmeal replacement, although it is required to guarantee the sustainability of aquaculture (Martínez-Llorens et al. 2012; Monge-Ortiz et al. 2016, 2018). Moreover, there has been some research that has demonstrated the variation of ammonia excretion due to various degrees of fishmeal replacement on fish diet (Cheng et al. 2003; Engin et al. 2013; Estruch et al. 2018; Obirikorang et al. 2015). Besides changing ammonia excretion, experimental plant meal diets increase the amount of organic matter in the water, mainly due to lesser digestibility of nutrients (Davidson et al. 2013, 2016). Varying $\mathrm{C} / \mathrm{N}$ ratio of biofilter influent has been proved to affect biofilter performance by modifying the equilibrium between nitrifiers and heterotrophs in favor of the later (Zhu and Chen 2001; Michaud et al. 2006). Therefore, it should be interesting to conduct studies on nitrifying filter performance using live fish fed with diets in which a percentage of fish meal is substituted by plant ingredients to fully comprehend the applicability of such filters on future sustainable aquaculture systems.

Studies of postprandial excretion (Ballestrazzi et al. 1994; Estruch et al. 2018) demonstrate the increase of ammonia excretion after feeding; therefore, the effect of the feeding strategy (characterized by feeding rate and temporal feeding distribution) on the ammonia excretion and subsequent ammonia concentration in water should be studied as well. To our knowledge, there is no consensus on how the spreading of the feeding affects nitrification. Since there is no general recommendation on fish feeding strategy and fish diet for maximizing biofilter performance, this paper aims to evaluate daily nitrogen variations based on the selection of three specific diets (one control diet and two experimental diets, a fishmeal-based diet and a plant meal-based diet) and three feeding strategies (manual feeding, automatic feeding, and auto-demand feeding) with the objective to determine differences on nitrification rates. 
Table 1 Characteristics of the trickling filters used in this study

Fig. 1 Diagram of the experimental systems

\begin{tabular}{lll}
\hline Parameter & Unit & Value \\
\hline Water flow & $\mathrm{m}^{3} / \mathrm{h}$ & 1.08 \\
Biofilter diameter & $\mathrm{cm}$ & 38 \\
Biofilter cross-sectional area & $\mathrm{m}^{2}$ & 0.11 \\
Biofilter height & $\mathrm{cm}$ & 22 \\
Biofilter volume & $\mathrm{m}^{3}$ & 0.025 \\
Filer media-specific surface area & $\mathrm{m}^{2} / \mathrm{m}^{3}$ & 300 \\
Biofilter area & $\mathrm{m}^{2}$ & 7.5 \\
\hline
\end{tabular}

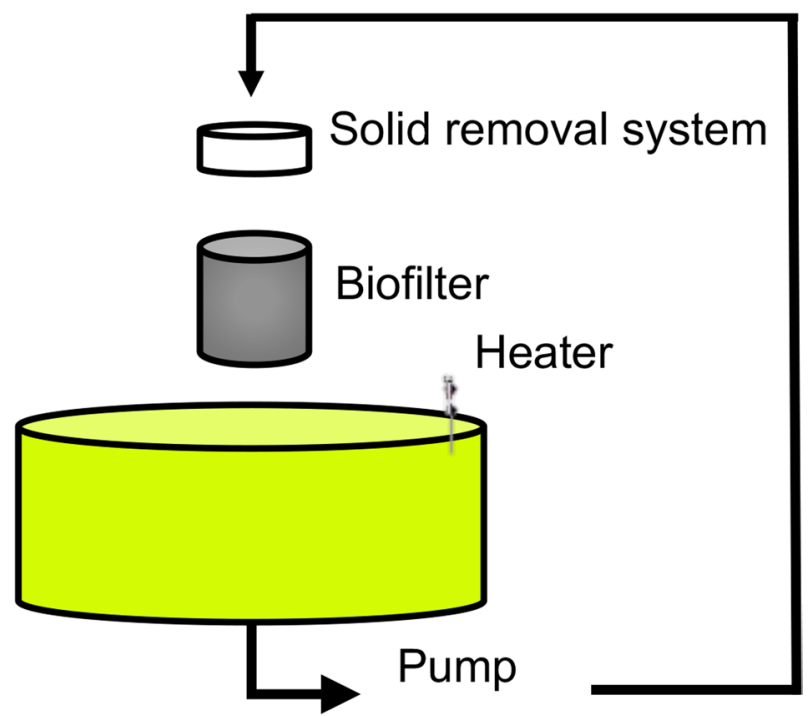

\section{Material and methods}

\section{Experimental system design}

Experiments were conducted on six independent recirculating aquaculture systems consisting in a fiberglass tank filled with $250 \mathrm{~L}$ of seawater, an associated biofilter, a plastic net covered with sponges which served as a solid removal unit, and a water pump (Oceanrunner® OR3500, Aqua-Medic ${ }^{\circledR}$, Bissendorf, Germany). The six recirculating systems were placed on the Laboratory of Aquaculture building in the Polytechnic University of Valencia (Spain). Biofilters were identical for every system and consisted in a plastic cube filled with Bactoballs ${ }^{\circledR}$ (Aqua-Medic ${ }^{\circledR}$, Bissendorf, Germany). Detailed characteristics of biofilters are presented in Table 1, and a simple diagram of the system is shown in Fig. 1. An internal heater (EHEIM thermocontrol 300, Eheim GmbH, Deizisau, Germany) was added to the tanks to keep water temperature at $22{ }^{\circ} \mathrm{C}$.

When the $\mathrm{pH}$ deviated from its values, weekly usually, the bulk water was partially replaced with fresh seawater that was stocked in a reserve water tank. Salinity was 
corrected accordingly by mixing stored seawater with dechlorinated freshwater. The sponges that formed the solid removal unit were cleaned once a week.

\section{Fish}

Gilthead sea bream (Sparus aurata) was acclimated on the main recirculation system of the Laboratorio de Acuicultura (LAC) from the Universitat Politècnica de València, composed by 2000 L-filled cylindrical fiberglass tanks (18), with $75 \mathrm{~m}^{3}$ of total capacity including a rotary mechanical filter and a $6 \mathrm{~m}^{3}$ capacity gravity biofilter. In that period, fish were fed with the control diet. After 2 weeks, 10 fish were slaughtered and used as the initial fish in the retention analyses, and 30 fish (mean weight $=7.9 \mathrm{~g}$ ) were placed in each tank. Fish were fed with their respective diet from Monday to Saturday, and feed intake was registered daily. Fish were weighted every month after being anaesthetized with $10 \mathrm{mg} \mathrm{L}^{-1}$ clove oil (Guinama ${ }^{\circledR}$ ), containing $87 \%$ eugenol.

Some individuals were slaughtered throughout the trial by a lethal bath with a high dose of clove oil $(150 \mathrm{mg} / \mathrm{L})$ and analyzed for proximate composition. Five fish per tank were sacrificed during the first change in feeding strategy ( 57 days after the beginning of the trial), and three fish per tank were sacrificed during the second change in feeding strategy (109 days after the beginning of the trial). Three fish per tank were slaughtered for the final proximate composition analysis.

\section{Fish diets and feeding strategies}

Three different diets were used in this experiment. One of the diets was a commercial diet which served as a control (CON), while the other two diets were mixed and pelleted using a semi-industrial twin-screw extruder (CLEXTRAL ${ }^{\circledR}$ BC-45, St. Etienne, France) at the feed producing laboratory of the Polytechnic University of Valencia. The processing conditions were $0.63 \mathrm{~g}$ screw speed, $110{ }^{\circ} \mathrm{C}$ temperature, and 30-40 atm. pressure. Ingredients of the experimental diets, as well as proximate composition of the three diets, are shown in Table 2. The proportion of the ingredients of the commercial diet was not made available but contained wheat red dog, soy meal, hydrolyzed feather meal, wheat gluten, rapeseed oil, soya bean oil, fish meal, calcium carbonate, maize gluten, monoammonium phosphate, sunflower seed meal, vital wheat gluten, fish oil, rapeseed vegetable oil, and whey powder. Every diet was assigned to two of the six individual RAS (details in Fig. 1) and was constant for the remainder of the study.

These diets were distributed by three different strategies, which were adopted consecutively, as explained in Table 3:

a) Manual feeding: feed was distributed to apparent satiation three times per day (9:00, 13:00, and 17:00). This was generally performed from Monday to Friday. On Saturdays, only one feeding was carried out and no feed was distributed on Sundays.

b) Use of automatic feeders: feed was distributed using aquarium disc feeders filled every day with a fixed ration. Feeders were operated to distribute a portion of the ration 4 times a day (10:00, 13:00, 16:00, and 19:00). The following day, if any feed remained in the feeder, it was weighted and subtracted from the amount of feed that was placed on the feeder the day before. Thus, the actual feed intake was registered daily. On Sundays, the automatic feeders were not filled. 
Table 2 List of ingredients and proximate composition of the experimental diets used in the study

\begin{tabular}{|c|c|c|c|}
\hline Ingredients $\left(\mathrm{g} \mathrm{kg}^{-1}\right)$ & Diets & Diets & \\
\hline & FM & $\mathbf{V M}$ & \\
\hline Fish meal & 590 & ---- & \\
\hline Wheat & 260 & ---- & \\
\hline Wheat gluten & ---- & 295 & \\
\hline Broad bean & ---- & 41 & \\
\hline Soybean meal & ---- & 182 & \\
\hline Pea meal & ---- & 41 & \\
\hline Sunflower seed meal & ---- & 158 & \\
\hline Soybean lecithin & 10 & 10 & \\
\hline Soybean oil & 92.8 & 90 & \\
\hline Fish oil & 38.2 & 90 & \\
\hline Calcium phosphate & ---- & 38 & \\
\hline Taurine & ---- & 20 & \\
\hline Methionine & ---- & 7 & \\
\hline Lysine & ---- & 10 & \\
\hline Arginine & ---- & 5 & \\
\hline Threonine & ---- & 3 & \\
\hline Vitamin mix & 10 & 10 & \\
\hline \multirow{2}{*}{$\begin{array}{l}\text { Proximate composition } \\
\text { (\% dry weight) }\end{array}$} & Diets & & \\
\hline & FM & VM & CON \\
\hline Dry matter & 88.1 & 93.9 & 93.6 \\
\hline Ash & 10.1 & 7.4 & 10 \\
\hline Crude protein & 44.2 & 45.0 & 59.0 \\
\hline Crude lipid & 18.5 & 19.8 & 18.5 \\
\hline Digestible protein & 42.7 & 41.8 & 48.6 \\
\hline Digestible energy $\left(\mathrm{kJ} \mathrm{g}^{-1}\right)$ & 21.74 & 21.68 & 20.04 \\
\hline $\mathrm{DP} / \mathrm{DE}\left(\mathrm{g} \mathrm{kJ}^{-1}\right)$ & 0.019 & 0.018 & 0.022 \\
\hline
\end{tabular}

c) Use of auto-demand feeders (Ad libitum): a weighted portion of fish feed was placed on the hopper of auto-demand feeders on a daily basis. The following day, the feed remaining on the hoppers was weighted and subtracted from the initial weighted portion for the calculation of the feed intake.

\section{Experimental analyses}

During fish growth, three series of experimental determinations were carried out: oxygen consumption estimation, ammonia excretion estimation, and ammonia removal rate determination. All of them were performed three times in every one of the 6 independent pilotscale RAS when fish were fed by a specific feeding strategy (thus, six measurements for every combination of diet and feeding strategy were performed in total). A comprehensive timetable of every trial is presented in Table 3. 
Table 3 Timetable of carried out experiments

\begin{tabular}{|c|c|}
\hline Date & Experimental determination \\
\hline Week 1 & Acclimation of fish fed by hand with every experimental diet \\
\hline Week 2 & Acclimation of fish fed by hand with every experimental diet \\
\hline Week 3 & Oxygen consumption + Ammonia excretion \\
\hline Week 4 & Oxygen consumption + Ammonia excretion \\
\hline Week 5 & Oxygen consumption + Ammonia excretion \\
\hline Week 6 & Ammonia removal rate \\
\hline Week 7 & Ammonia removal rate \\
\hline \multirow[t]{2}{*}{ Week 8} & Ammonia removal rate \\
\hline & Change of feeding strategy (placement of automatic feeders) \\
\hline Week 9 & Oxygen consumption + ammonia excretion \\
\hline Week 10 & Oxygen consumption + ammonia excretion \\
\hline Week 11 & Oxygen consumption + ammonia excretion \\
\hline Week 12 & Ammonia removal rate \\
\hline Week 13 & Ammonia removal rate \\
\hline \multirow[t]{2}{*}{ Week 14} & Ammonia removal rate \\
\hline & Change of feeding strategy (placement of auto-demand feeders) \\
\hline Week 15 & Oxygen consumption + ammonia excretion \\
\hline Week 16 & Oxygen consumption + ammonia excretion \\
\hline Week 17 & Oxygen consumption + ammonia excretion \\
\hline Week 18 & Ammonia removal rate \\
\hline Week 19 & Ammonia removal rate \\
\hline Week 20 & Ammonia removal rate \\
\hline Week 21 onwards & Digestibility trial \\
\hline
\end{tabular}

\section{Ammonia excretion and oxygen consumption trails}

Ammonia excretion was determined in a similar manner as in García-García et al. (2011). The pump that recirculated water in each one of the 6 RAS was turned off to avoid flow through the biofilter for $30 \mathrm{~min}$. Oxygen consumption was measured at the same time, and the aeration system was also turned off. Both dissolved oxygen and TAN were measured right after the interruption of the water flow and right before its reinstatement. This procedure was performed every $2 \mathrm{~h}$ in a 24-h cycle. Feeding was carried out as usual during the ammonia excretion/oxygen consumption trails.

Ammonia excretion and oxygen consumption rates were using Eq. 1 and Eq. 2, respectively. As both ammonia excretion and oxygen consumption decrease with increasing body weight (Cai and Summerfelt 1992), and the experiment was designed to change feeding strategies alongside the fish growth, mean weight of the fish was considered a co-variable when analyzing the effects of feeding strategy on ammonia excretion and oxygen consumption.

$$
\text { Ammonia excretion }\left(\frac{m g}{h}\right)=\frac{\text { Final } N-T A N(m g)-\operatorname{Initial} N-T A N(m g)}{\text { time }(h)}
$$




$$
\text { Oxygen consumption }\left(\frac{m g}{h}\right)=\frac{\text { Initial dissolved oxygen }(m g)-\text { Final disolved oxygen }(m g)}{\text { time }(h)}
$$

\section{Biofilter performance measurements}

During biofilter performance measurements, in which water flow through the biofilter remained as usual, TAN concentration in the bulk water was measured every $2 \mathrm{~h}$ in a 24-h cycle that coincided with the measurements carried out in the ammonia excretion/dissolved oxygen consumption trials. Bihourly, ammonia removal rates were calculated according to the following equation (Eq. 3):

$$
\text { Ammonia removal rate }\left(\frac{g N-T A N}{m 2 \text { day }}\right)=\frac{\text { Initial } N-\text { TAN mass }(t 0)+\text { Excreted } N-\text { TAN mass }(t 0 \text { to } t 1)-\text { Final } N-\text { TAN mass }(t 1)}{\text { bio filtration area } \times \text { time }(t 1)}
$$

The excreted N-TAN mass value was estimated from the ammonia excretion trials performed with the same fish (with similar weight) on the same tanks fed by the same combination of diet and feeding strategy during the same time frame. $\mathrm{pH}$, temperature, dissolved oxygen, nitrite, and nitrate were also analyzed every $2 \mathrm{~h}$.

\section{Nitrogen mass balance}

Crude protein in fish was analyzed as part of the proximate composition of the whole fish. The amount of nitrogen retained by fish based on protein intake was calculated for every diet (Eq. 4). Retained nitrogen and excreted nitrogen were used to elaborate a nitrogen mass balance similar to those described in Pedersen et al. (2012) and Morales et al. (2018).

$$
\text { Retained protein }(\%)=\frac{\left(\% \text { Protein }_{t 1} \times \text { Biomass }(g)_{t 1}\right)-\left(\% \text { Protein }_{t 0} \times \text { Biomass }(g)_{t 0}\right)}{\text { Feed intake }_{t 1-t 0} \times \% \text { Protein in diet }}
$$

\section{Digestibility experiment}

Digestibility experiment was carried out in the main recirculating aquaculture system of the Laboratorio de Acuicultura (LAC) of Universitat Politècnica de València. After every biofilter performance experiment was carried out, 5 fish per tank were randomly selected, placed in 2000 L-filled cylindrical fiberglass tanks, and fed with their respective feed including an inert marker (chromic oxide). Feces were collected every day by stripping. Protein content of feed and the feces as well as concentration of the inert marker of feed and feces was analyzed to calculate protein digestibility coefficients by the following equation, as described by Cho and Kaushik (1990):

$$
A P D C(\%)=100 \times\left(1-\left(\frac{F}{D} \times \frac{D C r}{F C r}\right)\right.
$$

where $\mathrm{F}$ is the percentage of protein in feces, $\mathrm{D}$ is the percentage of protein in the diet, $\mathrm{DCr}$ is the percentage of chromic oxide in the diet, and $\mathrm{FCr}$ is the percentage of chromic oxide in the feces. 


\section{Chemical analyses}

\section{Water quality parameter measurements}

Temperature and dissolved oxygen (where applicable) was measured by a Handy Polaris ${ }^{\circledR}$ oximeter (OxyGuard®, Farum, Denmark). pH was measured by a $\mathrm{pH}$ meter of the same brand (Handy Polaris ${ }^{\circledR} \mathrm{pH}$, OxyGuard ${ }^{\circledR}$, Farum, Denmark). For the measurement of TAN, $\mathrm{NO}_{2}{ }^{-}$, and $\mathrm{NO}_{3}{ }^{-}$, a $50 \mathrm{~mL}$ sample was taken and analyzed at the laboratory shortly after collection by spectrophotometry.

TAN was measured by the indophenol method after the addition of phenol, nitroprussiate, sodium citrate, and DTT. After $6 \mathrm{~h}$, the absorbance of the compound was measured at a wavelength equal to $640 \mathrm{~nm}$. Nitrite was measured by the Griess determination involving sulfanilamide and $\mathrm{N}-(1$-naphthyl)ethylenediamine dihydrochloride, which generates a pink/red dye whose absorbance (measured at $540 \mathrm{~nm}$ after $10 \mathrm{~min}$ ) is proportional as well to nitrite concentration. For the measuring of nitrate, a novel determination was carried out based on the use of vanadium(III) chloride as a reducing agent, first described in the paper of Miranda et al. (2001) and developed by Schnetger and Lehners (2014) for microplate readers. Measurements were carried out after approximately $24 \mathrm{~h}$ of reaction at room temperature. TAN and nitrite were measured using a T60V UV-vis spectrophotometer (PG Instruments, Leicester, UK), while nitrate determinations were performed with a Victor 1420 microplate reader (Perkin Elmer, formerly Wallac Oy, Massachusetts, USA).

\section{Fish and diets proximate composition}

Proximate composition of the experimental diets and whole-body fish were determined according to the following procedures, after homogenization with a Waring $®$ lab bender (Conair Corporation, One Cummings Point Road, Stamford, USA): moisture was determined by oven thermal drying at $105^{\circ} \mathrm{C}$ to constant weight, ash by combustion in a muffle at $550{ }^{\circ} \mathrm{C}$ overnight. Carbon and nitrogen were analyzed by the Dumas principle (TruSpec CN; Leco Corporation, St. Joseph, MI, USA) and used to determine protein content and energy. Energy was calculated according to Brouwer (1965), from the $\mathrm{C}(\mathrm{g})$ and $\mathrm{N}(\mathrm{g})$ balance $(\mathrm{GE}=51.8 \times \mathrm{C}+19.4 \times \mathrm{N})$. Crude lipid was determined by diethyl ether extraction using an ANKOM XT10 extractor.

\section{Digestibility}

Chromic oxide (the inert marker used for the digestibility experiments) was determined in the diets and in the feces collected from the fish by stripping after acidic digestion with $\mathrm{HNO}_{3} 1.5 \mathrm{~N}+\mathrm{KCl} 0.38 \%$. The chromic oxide (VI) produced by the acidic digestion was measured by molecular spectrophotometry after the reaction with 1,5-diphenylcarbazide, which produces a red/violet compound whose absorbance $(550 \mathrm{~nm})$ is dependent of the chromic oxide concentration. This procedure was performed using the article of Bremer Neto et al. (2005) as a reference.

\section{Data processing and statistics}

$\mathrm{pH}$, dissolved oxygen, and temperature data did not require any processing. TAN concentration was converted into nitrogen mass present in the ammonia molecule (mgN-TAN). 
Both hourly and daily, ammonia excretion and oxygen consumption rates are presented. Daily ammonia excretion and daily oxygen consumption were estimated by pooling all the results obtained in a 24-h cycle of measurements. Ammonia removal rates are presented as $\mathrm{g}$ of N-TAN removed divided by biofiltration area (identical for every tank) and day and were pooled from all the bihourly measured ammonia removal rates.

One-way and multivariate ANOVAS were performed to determine significant differences between single and combined treatments, respectively. All statistical analyses were carried out using Statgraphics® Centurion v.XVII.II for Windows ${ }^{\circledR}$.

\section{Ethical statement}

This study has complied with the European Union Council Directive 2010/63/ UE, which lays down minimum standards for animal protection under experimentation, and it was also in accordance with Spanish national legislation (Spanish Royal Decree 53/2013), which regulates animal usage in experimentation and/or for other scientific purposes. Fish were checked daily and anesthetized with clove oil ( $1 \mathrm{~mL} 100 \mathrm{~mL}^{-1}$ of rearing water) before handling.

\section{Results}

\section{Growth, survival, and proximate composition}

Growth (Fig. 2) was constant but uneven among the fish groups, in correspondence with the quality of the fish feed. The protein-rich commercial diet led to the highest mean weight of the fish (Table 4) being the experimental fishmeal diet the second best feed for growth. Differences in growth between those groups (control and experimental fishmeal diet) were

\section{Growth}
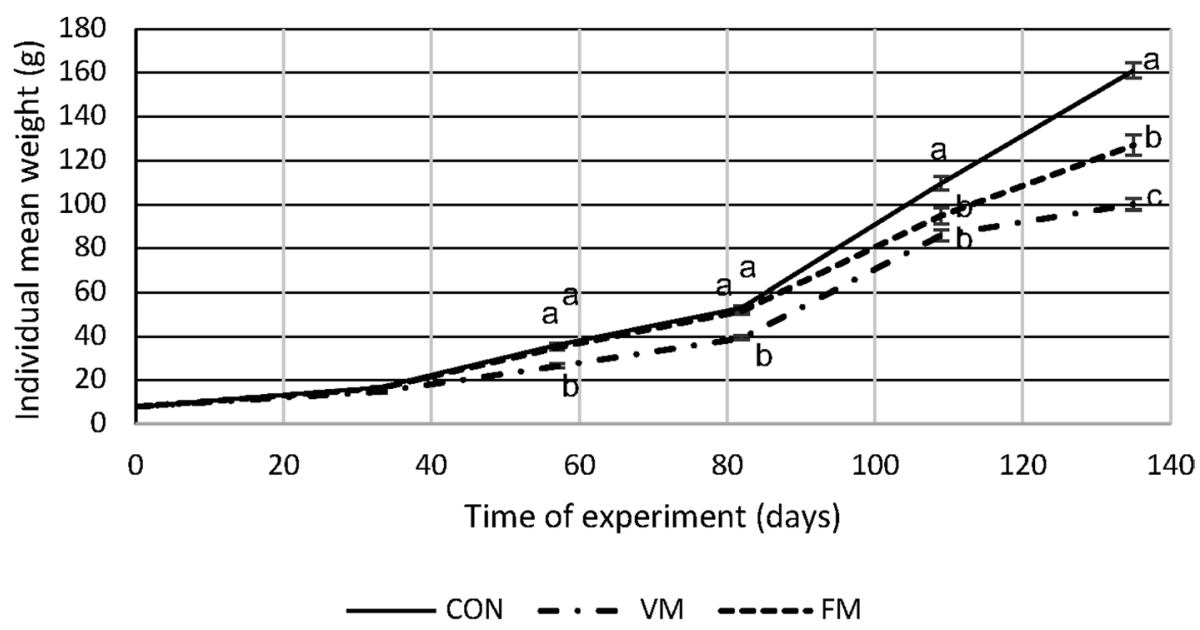

Fig. 2 Mean weight (+ standard error) of the fish depending on fish diet 
Table 4 Performance of gilthead sea bream throughout the study

\begin{tabular}{|c|c|c|c|c|c|c|}
\hline & \multicolumn{4}{|c|}{ Experimental diets } & \multirow[b]{2}{*}{ SEM } & \multirow[b]{2}{*}{ p-value } \\
\hline & CONTROL & $F M$ & $V M$ & Mean & & \\
\hline Initial weight (g) & 9.7 & 9.7 & 9.7 & & & \\
\hline Final weight $(\mathrm{g})$ & $161^{\mathrm{a}}$ & $127^{\mathrm{ab}}$ & $100^{\mathrm{b}}$ & 129 & 8.2 & 0.0307 \\
\hline Survival (\%) & $98.3^{\mathrm{a}}$ & $88.3^{\mathrm{ab}}$ & $76.7^{\mathrm{b}}$ & 87.8 & 3.04 & 0.0343 \\
\hline SGR (\%/day) & $2.23^{\mathrm{a}}$ & $2.05^{\mathrm{ab}}$ & $1.88^{\mathrm{b}}$ & 2.05 & 0.05 & 0.0355 \\
\hline $\begin{array}{l}\text { Feed intake } \\
\text { (g/100 } \mathrm{g} \text { fish) }\end{array}$ & $1.51^{\mathrm{c}}$ & $1.67^{\mathrm{b}}$ & $2.06^{\mathrm{a}}$ & 1.75 & 0.26 & 0.0014 \\
\hline Feed conversion ratio & $1.17^{\mathrm{c}}$ & $1.35^{\mathrm{b}}$ & $1.80^{\mathrm{a}}$ & 1.44 & 0.03 & 0.0015 \\
\hline
\end{tabular}

Different superscripts in the same row indicate significant differences $(p<0.05)$

practically nonexistent up until the 82nd day of the trial, when differences in mean weight started to become more apparent. The plant meal-based diet started to impair growth very early on the study.

\section{Oxygen consumption}

As shown in Fig. 3, the variation patterns in oxygen consumption were similar for each diet irrespective of feeding strategy, although they were quite different between feeding strategies. After a constant rise that stopped after $6 \mathrm{~h}$ approximately, oxygen consumption rate was somewhat constant in the trial in which feed was given ad libitum to the fish, whereas hourly oxygen consumption varied more abruptly in fish fed by manual and automatic feeding strategies. A possible relationship between feeding and oxygen consumption rate must be considered for those feeding strategies.

There were significant differences in daily oxygen consumption between diets (Table 5). Fish belonging to the VM group presented a higher significant oxygen consumption rate, including and not including consumed feed into account $\left(460.15 \pm 44.25 \mathrm{gO}_{2}\right.$ consumed

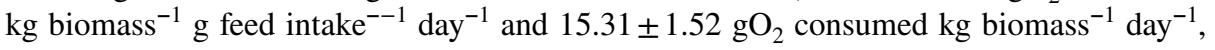
respectively). No significant differences were found between the remaining diets.

Feeding strategy was also proven to be significantly influent on oxygen consumption ( $p$-values $=0.0049$ and 0.0319 for rates without including feed intake and including feed intake, respectively) (Table 6). The manual feeding strategy led to the mean oxygen consumption rate $\left(16.04 \pm 0.69 \mathrm{gO}_{2}\right.$ consumed kg biomass ${ }^{-1}$ day ${ }^{-1}$ and $511.73 \pm 34.30 \mathrm{mgO}_{2}$ consumed kg biomass ${ }^{-1} \mathrm{~g}$ feed intake $\mathrm{kay}^{-1}$ ). Although the auto-demand feeding strategy led to the second highest absolute oxygen consumption, results did vary when feed intake was taken into account (Table 6, second column). In that case, the automatic feeding strategy led to the second highest oxygen consumption rate $\left(379.08 \mathrm{mgO}_{2}\right.$ consumed $\mathrm{kg}$ biomass $^{-1} \mathrm{~g}$ feed intake ${ }^{-1} \mathrm{day}^{-1}$ ), while the auto-demand feeding strategy led to the lowest oxygen consumption rate $\left(284.01 \mathrm{mgO}_{2}\right.$ consumed $\mathrm{kg}_{\text {biomass }}{ }^{-1} \mathrm{~g}_{\text {feed intake }}{ }^{-1}$ day $\left.^{-1}\right)$.

An additional ANCOVA analysis proved the mean weight to be a significant co-variable for the oxygen consumption rate results, both including and not including feed intake as a part of the oxygen consumption rate ( $p$-values $=0.0162$ and 0.0026 ), which will be considered when discussing the results. No other variables did have a significant effect ( $p$-value $>0.05)$ when considering them as co-variables. 

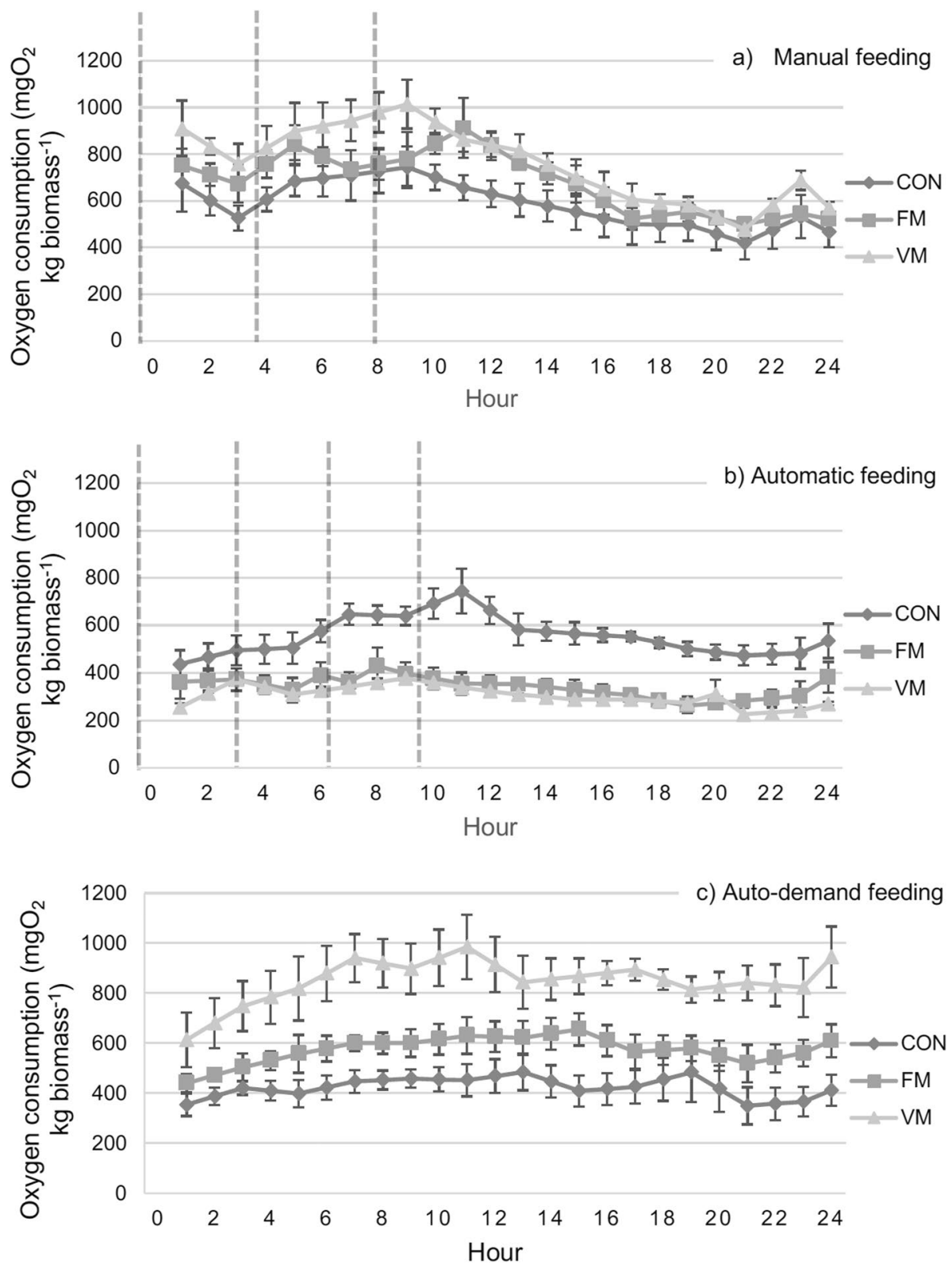

Fig. 3 Mean oxygen consumption rates' (+ standard errors) hourly variation selected by feed for every feeding strategy. Dashed lines indicate periods of feeding when applicable

The influence of every combination of factors on the mean oxygen consumption rate is shown in Figs. 4 and 5. Fish whose oxygen consumption was the highest $(20.06 \pm 1.80$ $\mathrm{gO}_{2}$ consumed $\mathrm{kg}$ biomass ${ }^{-1}$ day $^{-1}$ ) were in the group fed with the VM diet with autodemand feeders. 
Table 5 Mean daily oxygen consumption rates depending on feeding diet

\begin{tabular}{|c|c|c|c|}
\hline \multirow[t]{2}{*}{ Diet } & \multirow[t]{2}{*}{$n$} & \multicolumn{2}{|l|}{ Oxygen consumption } \\
\hline & & $\mathrm{gO}_{2} \mathrm{~kg}$ biomass $^{-1} \mathrm{day}^{-1}$ & $\begin{array}{l}\mathrm{mgO}_{2} \mathrm{~kg} \text { bio- } \\
\text { mass }^{-1} \mathrm{~g} \text { feed } \\
\text { intake }^{-1} \text { day }^{-1}\end{array}$ \\
\hline $\mathrm{CON}$ & 18 & $12.48 \pm 0.77^{\mathrm{b}}$ & $344.439 \pm 39.30^{\mathrm{b}}$ \\
\hline FM & 18 & $12.79 \pm 0.95^{b}$ & $370.243 \pm 41.11^{\mathrm{b}}$ \\
\hline VM & 18 & $15.31 \pm 1.52^{\mathrm{a}}$ & $460.146 \pm 44.24^{\mathrm{a}}$ \\
\hline
\end{tabular}

Different superscripts in the same column indicate significant differences $(p$-value $<0.05)$

Table 6 Mean oxygen consumption rates depending on feeding strategy

\begin{tabular}{llll}
\hline Feeding strategy & $n$ & Oxygen consumption & \\
\cline { 3 - 4 } & & $\mathrm{gO} \mathrm{kg} \mathrm{biomass}^{-1}$ day $^{-1}$ & $\begin{array}{l}\mathrm{mgO}_{2} \mathrm{~kg} \mathrm{bio-}_{\text {bass }}^{-1} \text { feed }_{\text {feed }} \\
\text { intake }^{-1} \text { day }^{-1}\end{array}$ \\
\hline Manual feeding & 18 & $16.04 \pm 0.69^{\mathrm{a}}$ & $511.74 \pm 34.30^{\mathrm{b}}$ \\
Automatic feeding & 18 & $9.67 \pm 0.74^{\mathrm{b}}$ & $379.08 \pm 31.59^{\mathrm{b}}$ \\
Auto-demand feeding & 18 & $14.88 \pm 1.31^{\mathrm{a}}$ & $284.01 \pm 43.73^{\mathrm{a}}$
\end{tabular}

Different superscripts in the same column indicate significant differences $(p$-value $<0.05)$

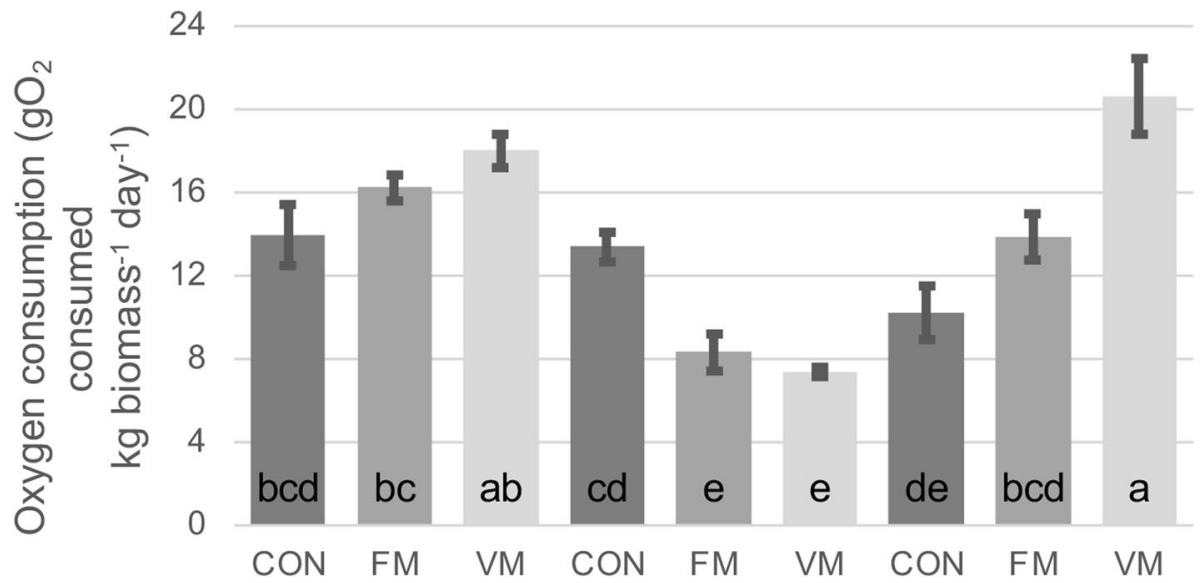

\section{Combination of diet and feeding strategy}

Fig. 4 Mean oxygen consumption (+standard errors) $(n=6)$ for every combination of diet and feeding strategy, standardized by fish biomass. Different letters in tags indicate significant differences $(p$-value $<0.05)$ 


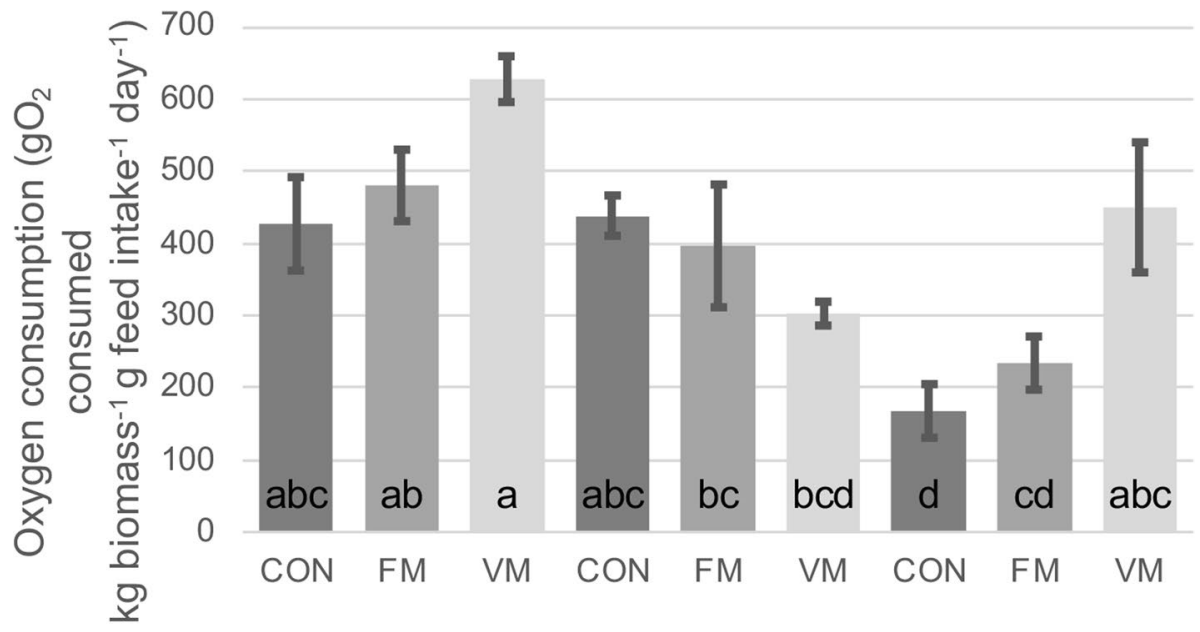

\section{Combination of diet and feeding strategy}

Fig. 5 Mean oxygen consumption (+standard errors) $(n=6)$ for every combination of diet and feeding strategy, standardized by fish biomass and feed intake. Different letters in tags indicate significant differences $(p$-value $<0.05)$

\section{Ammonia excretion}

Figure 6 represents the variation of ammonia excreted throughout the day. Sudden raises in ammonia excretion followed manual feedings, more acutely pronounced that in the case of oxygen consumption rates, particularly for fish fed the control diet. When fish were fed with feeders (either automatic or auto-demand), the ammonia excretion was particularly low and more constant throughout the day.

Daily ammonia excretion was also affected by both diet (Table 7) and feeding strategy (Table 8). Fish fed with the control diet excreted significantly higher ammonia (777.9 \pm 56.7 mgN-TAN kg${ }^{-1}$ day $^{-1}$ ), whereas no significant differences were found among the remaining diets. On the other hand, both the control diet and the VM diets excreted significantly higher daily ammonia per $g$ of feed intake $(20.13 \pm 1.91 \mathrm{mgN}-\mathrm{TAN}$ and $18.65 \pm 2.97 \mathrm{mgN}$ TAN, respectively) than fish fed the FM diet.

Considering feeding strategies, fish fed manually excreted the most daily ammonia on average, either per $\mathrm{kg}$ of fish and per $\mathrm{kg}$ of fish or $\mathrm{g}$ of feed intake. Concretely, a mean excretion of $849.25 \pm 68.32 \mathrm{mgN}^{-T A N ~ k g}$ biomass $^{-1}$ day $^{-1}$ and $26.52 \pm 2.21 \mathrm{mgN}-\mathrm{TAN}$ $\mathrm{kg}_{\text {biomass }}{ }^{-1} \mathrm{~g}$ feed intake ${ }^{-1}$ day $^{-1}$ was observed. Mean ammonia excretion rate via automatic feeding was significantly higher $\left(15.30 \pm 1.54\right.$ mgN-TAN kg biomass $^{-1} \mathrm{~g}$ feed intake $^{-1}$ day $^{-1}$ ) than mean ammonia excretion rate when fish were fed by auto-demand feeders $\left(10.48 \pm 0.91 \mathrm{mgN}^{-T A N ~ k g}\right.$ biomass $\left.^{-1} \mathrm{~g}_{\text {feed intake }}{ }^{-1} \mathrm{day}^{-1}\right)$, considering feed intake. Nevertheless, while considering ammonia excretion per $\mathrm{kg}$ of fish, it was higher for the fish fed via auto-demand feeders $\left(614.34 \pm 60.93 \mathrm{mgN}^{-T A N ~ k g}\right.$ biomass $^{-1}$ day $\left.^{-1}\right)$ than for the fish fed via automatic feeders $\left(405.61 \pm 49.48 \mathrm{mgN}^{-T A N ~ k g}\right.$ biomass $\left.^{-1} \mathrm{day}^{-1}\right)$. Contrary to oxygen excretion, mean weight did not have an effect on ammonia excretion ( $p$-value $>0.05)$, neither did any other possible co-variables. 


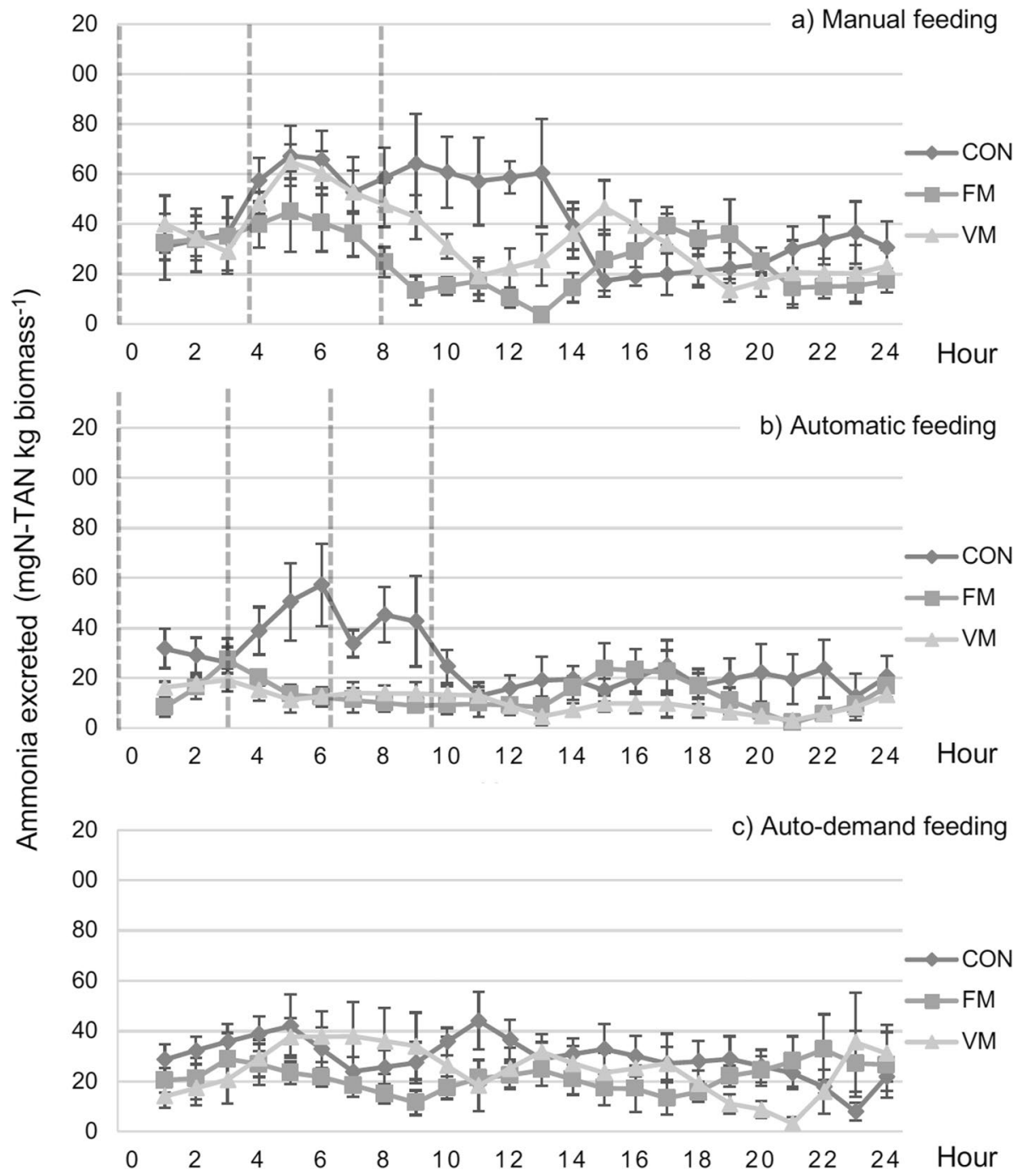

Fig. 6 Ammonia excretion rates' (+standard errors) hourly variation selected by feed for every feeding strategy. Dashed lines indicate periods of feeding when applicable

Table 7 Mean ammonia excretion rates depending on the different diets fed

\begin{tabular}{|c|c|c|c|}
\hline \multirow[t]{2}{*}{ Diet } & \multirow[t]{2}{*}{$n$} & \multicolumn{2}{|l|}{ Ammonia excretion } \\
\hline & & $\begin{array}{l}\text { mgN-TAN kg bio- } \\
\text { mass }^{-1} \text { day }^{-1}\end{array}$ & $\begin{array}{l}\text { mgN-TAN kg } \\
\text { biomass }^{-1} \mathrm{~g} \text { feed } \\
\text { intake }^{-1} \text { day }^{-1}\end{array}$ \\
\hline CONTROL & 18 & $777.87 \pm 56.67^{\mathrm{a}}$ & $20.13 \pm 1.91^{\mathrm{a}}$ \\
\hline FM & 18 & $481.46 \pm 45.78^{\mathrm{b}}$ & $13.52 \pm 1.47^{\mathrm{b}}$ \\
\hline VM & 18 & $609.87 \pm 93.36^{\mathrm{b}}$ & $18.65 \pm 2.97^{\mathrm{a}}$ \\
\hline
\end{tabular}

Different superscripts in the same column indicate significant differences $(p$-value $<0.05)$ 
Table 8 Mean ammonia excretion rates depending on feeding strategy

\begin{tabular}{|c|c|c|c|}
\hline \multirow[t]{2}{*}{ Feeding strategy } & \multirow[t]{2}{*}{$n$} & \multicolumn{2}{|c|}{ Ammonia excretion } \\
\hline & & $\begin{array}{l}\text { mgN-TAN } \\
\text { kg bio- } \\
\text { mass }^{-1} \text { day }^{-1}\end{array}$ & $\begin{array}{l}\text { mgN-TAN kg } \\
\text { biomass }^{-1} \mathrm{~g} \text { feed } \\
\text { intake }^{-1} \text { day }^{-1}\end{array}$ \\
\hline Manual feeding & 18 & $800.35 \pm 58.58^{a}$ & $25.64 \pm 2.60^{\mathrm{a}}$ \\
\hline Automatic feeding & 18 & $405.61 \pm 49.48^{\mathrm{c}}$ & $15.30 \pm 1.54^{\mathrm{b}}$ \\
\hline Auto-demand feeding & 18 & $612.83 \pm 59.96^{\mathrm{b}}$ & $10.48 \pm 0.91^{\mathrm{c}}$ \\
\hline
\end{tabular}

Different superscripts in the same column indicate significant differences $(p$-value $<0.05)$

When taking all combination of factors into consideration (Fig. 7 and Fig. 8), fish whose ammonia excretion was the biggest $\left(983.28 \pm 92.52\right.$ mgN-TAN kg biomass ${ }^{-1}$ day $\left.^{-1}\right)$ were in the group fed with the $\mathrm{CON}$ diet to satiation (manual feeding).

\section{Nitrogen balance}

Nitrogen retention, ammonia excretion rates, and solid nitrogenous waste (calculated as 100 - ADC of the nitrogen for every diet) are represented in a nitrogen mass balance (Fig. 9). There were differences between diets for every one of the nitrogenous waste fractions. Nitrogen retention was about $30 \%$ for every diet, and there were significant unaccounted sources of nitrogen, especially in the case of the experimental diets (FM and VM).

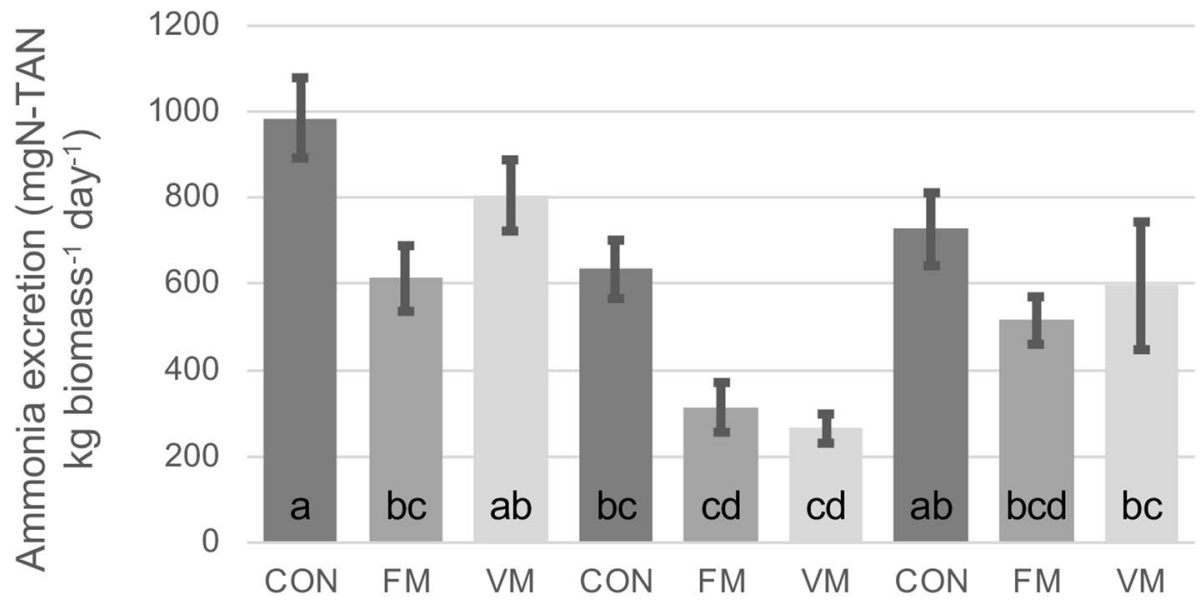

\section{Combination of diet and feeding strategy}

Fig. 7 Mean ammonia excretion rate (+standard errors) $(n=6)$ for every combination of diet and feeding strategy, standardized by fish biomass. Different letters in tags indicate significant differences $(p$-value $<0.05)$ 


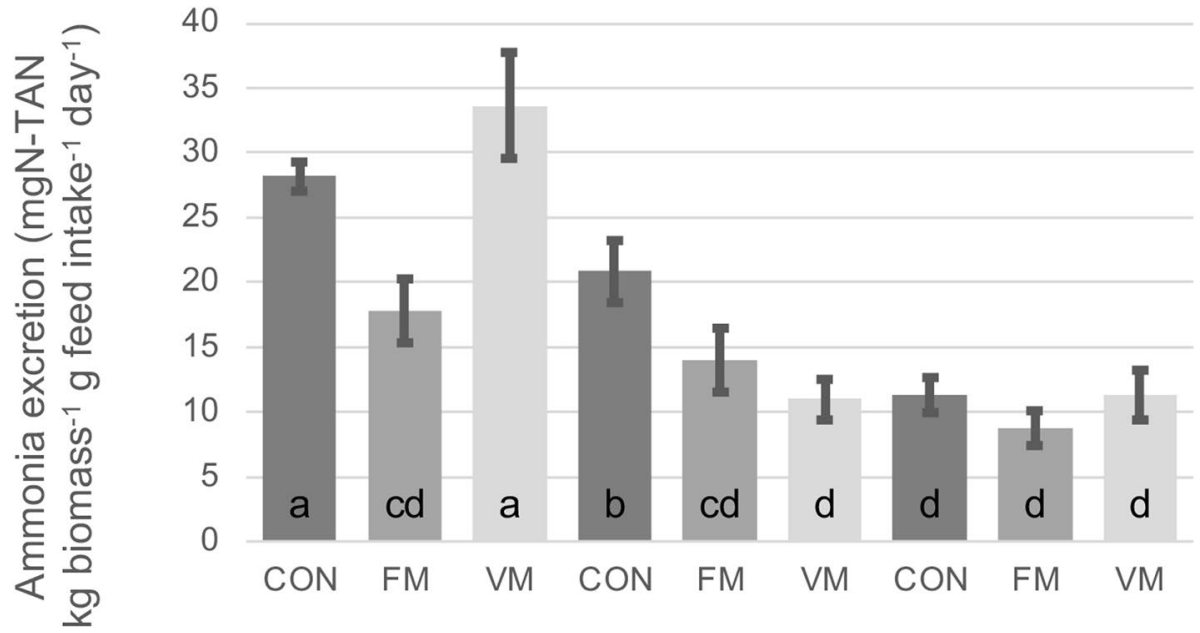

\section{Combination of diet and feeding strategy}

Fig. 8 Mean ammonia excretion rate (+standard errors) $(n=6)$ for every combination of diet and feeding strategy, standardized by fish biomass and feed intake. Different letters in tags indicate significant differences $(p$-value $<0.05)$

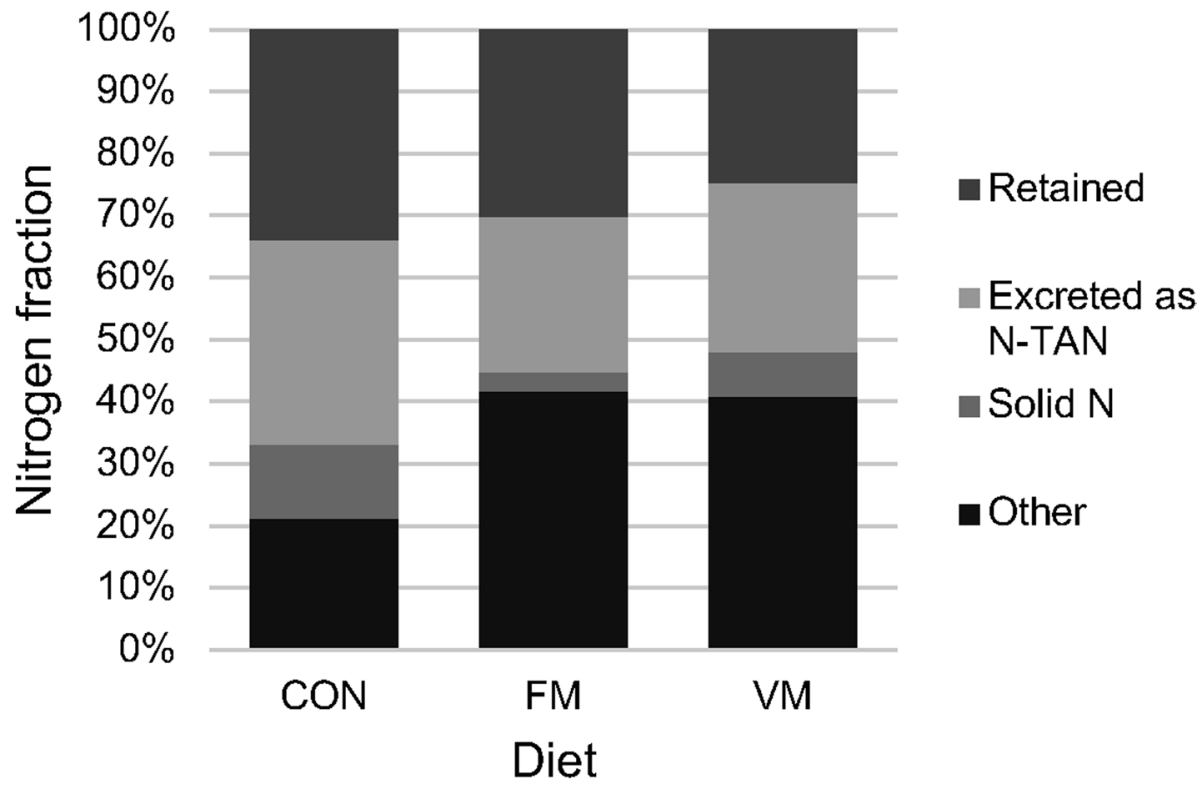

Fig. 9 Nitrogen fraction allocation of dietary protein intake for every experimental diet 
Table 9 Ammonia removal rates depending on the different diets fed

\begin{tabular}{lll}
\hline Diet & $n$ & $\begin{array}{l}\text { Ammonia removal rate } \\
(\mathrm{gN}-\text { TAN removed } \\
\mathrm{m}^{-2} \text { biofiltration area } \\
\left(a y^{-1}\right)\end{array}$ \\
\hline CONTROL & 18 & $0.11 \pm 0.01^{\mathrm{a}}$ \\
FM & 18 & $0.06 \pm 0.01^{\mathrm{b}}$ \\
VM & 18 & $0.05 \pm 0.01^{\mathrm{b}}$ \\
\hline
\end{tabular}

Different superscripts indicate significant differences $(p$-value $<0.05)$

\begin{tabular}{lll}
\hline Feeding strategy & $n$ & $\begin{array}{l}\text { Ammonia removal rate } \\
(\mathrm{gN}-\text { TAN removed } \\
\mathrm{m}^{-2} \text { biofiltration area } \\
\text { day }\end{array}$ \\
\hline Manual & 18 & $0.05 \pm 0.01^{\mathrm{b}}$ \\
Automatic & 18 & $0.07 \pm 0.01^{\mathrm{b}}$ \\
Auto-demand & 18 & $0.10 \pm 0.01^{\mathrm{a}}$
\end{tabular}

Different superscripts indicate significant differences $(p$-value $<0.05)$
Table 10 Ammonia removal rates depending on the different feeding strategies

\section{Biofilter performance}

Biofilters in trials with fish fed with the control diet removed the most ammonia from water $\left(0.11 \pm 0.01 \mathrm{gN}-\mathrm{TAN}\right.$ removed $\mathrm{m}^{-2}$ biofiltration area day $\left.{ }^{-1}\right)$. There were no significant differences between the remaining experimental groups (Tables 7, 9 and 10). The use of autodemand feeders led to the significantly greater mean ammonia removal rate by the biofilters, with no significant differences between the remaining feeding strategies (Table 7).

The effect of the combination of diet and feeding strategy is represented in Fig. 10, as well as the maximum ammonia found on the rearing one among the samples that were measured every $2 \mathrm{~h}$. Every concentration, as well as the measurements of nitrite and nitrate, is shown in Fig. 11 for every combination of diet and feeding strategy. Any amount of N-TAN that could have been present at the beginning of the trials was standardized to zero and was subtracted from each sample to facilitate comprehension.

Ammonia removal rates were particularly high when feed was distributed by autodemand feeders, and the use of the control diet led to generally higher removal among every feeding strategy. In the case of the manual feeding as well as in the case of the automatic feeding strategy, there was a close relationship between the maximum N-TAN found in water and the ammonia removal rate; nevertheless in the case of the auto-demand feeders, there were no differences in maximum N-TAN, although there were noticeably different ammonia removal capabilities.

Concentrations of N-TAN (Fig. 11) during the day were particularly high (it exceeded $100 \mathrm{mg}$ in certain moments in the case of the manual and automatic feeding) for the control diet. There were no noticeable differences in mean N-TAN between feeding strategies for the experimental diets (FM and VM). The remaining nitrogenous substances $\left(\mathrm{N}^{-\mathrm{NO}_{2}}{ }^{-}\right.$and $\mathrm{N}-\mathrm{NO}_{3}{ }^{-}$) were mainly high for the control diet as well for the auto-demand feeding strategies for the FM and the VM diet, consequence of the higher nitrification. In general, the rise and drop of the N-TAN and the $\mathrm{N}^{-\mathrm{NO}_{2}}{ }^{-}$occurred for every combination of process 


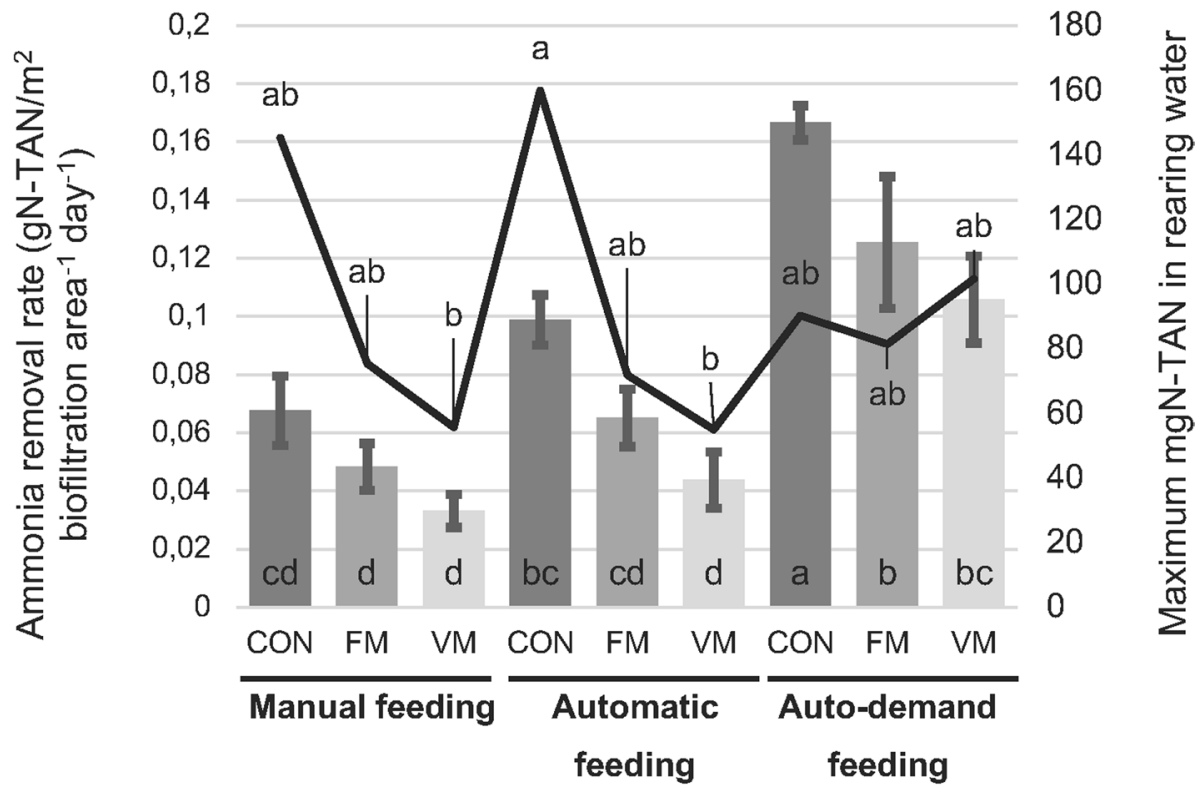

\section{Combination of diet and feeding strategy}

Fig. 10 Effect of the combination of diet and feeding strategy on ammonia removal rates (bars) and maximum mg N-TAN in water (solid line). Different letters indicate significant differences $(p$-value $<0.05)$

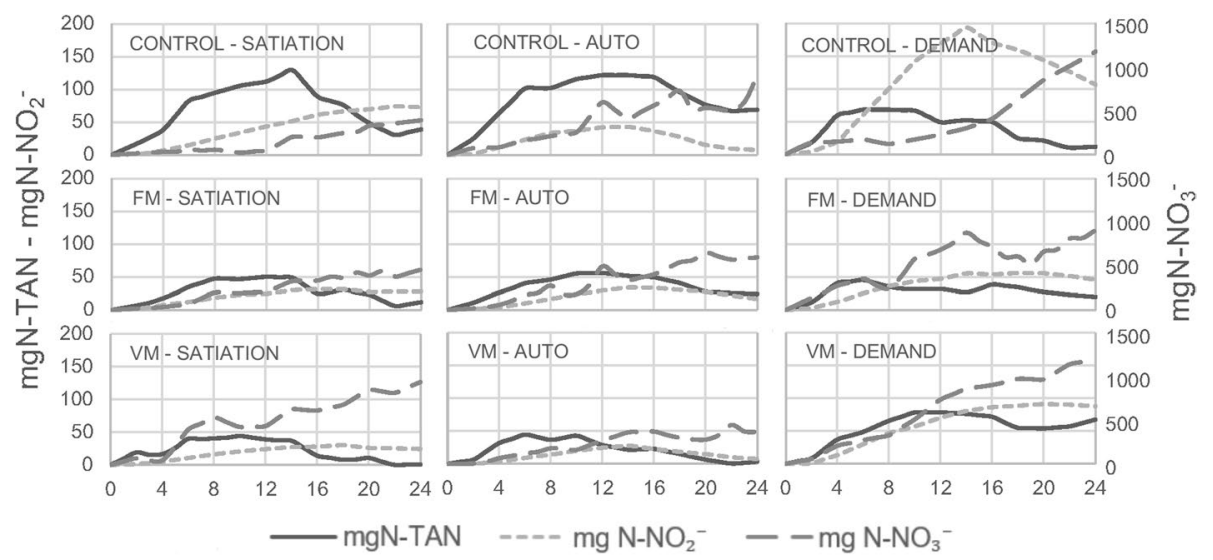

Fig. 11 Concentration of nitrogenous compounds during the biofilter performance trials. Graph titles indicate the combination of variables whose influence on ammonia removal rates was investigated

parameters, although the ammonia peaks are more noticeable in the case of the manual and the automatic feeding strategy with limited feedings. $\mathrm{NO}_{2}{ }^{-}$only showed an unexpected behavior for the combination of control diet and auto-demand feeding strategy, in which their peak was higher than for any other combination, suggesting a possible impairment of the nitrite oxidizing bacteria. 


\section{Discussion}

This article reports an essay of marine water fish production (Sparus aurata in this case) in a pilot-scale RAS with appropriately sized biofilters fed with experimental diets compared to a control diet, with focus on biofilter efficiency. The size of the biofilters, as well as reactor-specific parameters such as filter media and hydraulic loading, was adopted from previous studies with optimal results (Godoy-Olmos et al. 2016, 2019).

Fishmeal replacement (VM diet) was apparently responsible for the significant differences observed for survival, specific growth rate, as well as other nutritional aspects such as nitrogen retention. Diets without animal meals as protein source have been proved detrimental to fish welfare in different scale RAS (Estruch et al. 2018; Monge-Ortiz et al. 2018). On the contrary, both the control and the FM diet yielded satisfactory results when comparing SGR and FCR values with similar growth studies on RAS systems (MartínezLlorens et al. 2012). Fish adapted reasonably well to all of the feeding strategies carried out on this study, with some brief periods of acclimation.

Nitrogenous waste characterization was on the other hand also similar to those found in literature (Dalsgaard and Pedersen 2011; Morales et al. 2018) retained and excreted as TAN nitrogen was similar (around 30\%), while the fraction of solid nitrogen was distinctly lower (3-12\%) than similar studies which use commercial diets. In our specific study, the three diets were very different in ingredients and nutrient digestibility, which may explain the differences. There also were sources of nitrogen not accounted in the study (that is, nitrogen ingested was not equal to the sum to retained nitrogen + solid waste + dissolved waste). Among the unaccounted $\mathrm{N}$ sources, there are other nitrogenous substances excreted by fish, not determined in this study. Urea $\mathrm{N}$, for instance, may represent around $12 \%$ of the total nitrogenous excretion (Dalsgaard et al. 2015). Other unaccounted nitrogenous excretions have also been reported (10\% according to Dalsgaard et al. (2015)), consisting in entire amino acids (4-10\%) or mucoproteins (3-11\%) which are excreted regularly (Wood 2001; Kajimura et al. 2004). Differences in analytical methods might also affect nitrogen characterization (Kajimura et al. 2004; Pedersen et al. 2012).

Finally, nitrogen lixiviated from unconsumed feed is another important source of unaccounted nitrogen for this study. Although solids were removed from water regularly with the solid-removal system, pellets may be dissolved before the water flow carries them to the filter, leading to an increase in dissolved nitrogen. In our study, the control diet was the more stable, whereas the experimental diets were more unstable. The relationship between stability and nutrient leeching has been discussed elsewhere (Fagbenro and Jauncey 1995), as well as the influence of experimental ingredients in the stability of fish diets (Hoyos et al. 2017). This degree of disintegration is surely one of the reasons for the higher unaccounted nitrogen for the experimental diets (FM and VM) in comparison with the control diet, which was more compact. In addition, the specific characteristics of the auto-demand feeding strategy impede unconsumed feed recollection; therefore, it was decided not to collect and subtract unconsumed feed from the daily feed intake. Nevertheless, even if some feed is lost, it is assumed that the degree of feed lost is proportional to the amount of feed intake for a given feeding strategy, and the proportion of feed lost is relative to the feeding strategy.

Fish weight did influence oxygen consumption as expected. Juvenile fish (which in the study coincided with the manual feeding strategy) consumed more oxygen per $\mathrm{g}$ of feed than on-growing fish, as observed in other studies (Cerezo Valverde and García García 2004; Steinarsson and Moksness 1996). Nevertheless, both diet and feeding strategy were 
also significant in mean oxygen consumption rates ( $p$-values of 0.0160 and 0.0000 , respectively). The differential feeding intake consequence of the feeding strategy used might be partially responsible for the differential total oxygen consumption, as the feed intake for the auto-demand feeding strategy was higher than for the other two. Guinea and Fernandez (1997) reported significant differences in oxygen consumption when feeding rate was increased from $1 \%$ of body weight to $2 \%$ but did not find significant differences when the same ration ( $1 \%$ body weight) was distributed in one or two feedings. The higher metabolic effort invested in activating the mechanism to release the feed in the auto-demand feeders might be another possible explanation of the increased oxygen consumption.

The differential oxygen consumption depending on diet may be attributed to general stress of the fish fed with the plant meal-based diet compared with the other two groups. Replacement of fish meal by plant protein sources leads to immunosuppression as well as an increment in oxidative stress, especially if replaced on its entirety (Sitjà-Bobadilla et al. 2005). This higher stress and immunosuppression attributed to VM group was probably responsible of the lower survival rate (Estruch et al. 2018). Finally, the inferior digestibility which is a factor of increased organic matter may also suppose an increment in oxygen consumption due to the increased BOD in biofilter influent (Fernandes et al. 2015).

The protein-rich control diet led to the highest ammonia excretion without considering feed intake, whereas there were no differences between the remaining diets. However, significant differences between the ammonia excretion of the fish fed with the FM and the VM diets were found when analyzing ammonia excretion by feed intake, and no significant differences were found between the control and VM diets.

It could be therefore deduced that the reduced absolute ammonia excretion (mgN-TAN $\mathrm{kg}$ biomass $^{-1}$ day $^{-1}$ ) of the VM diet was a consequence of the low feed intake rather than the quality of the diet, as fish fed with diets in which fish meal has been replaced with plant protein do have an increase ammonia excretion (Cheng et al. 2003; Obirikorang et al. 2015). This increase in ammonia excretion may be caused by the anti-nutritional factors present in them which affect protein digestibility (Francis et al. 2001; Kokou and Fountoulaki 2018). The incomplete digestion of protein leads to the alteration of the bioavailability of amino acids, which coupled with the poor amino acidic balance of the proteins of plant origin which ultimately leads to insufficient absorption. Berge et al. (2004) demonstrated that the absence of neutral amino acids impairs the uptake of essential ones like L-methionine. The inclusion of synthetic amino acids is suggested to improve the amino acidic balance of the plants without fish meal (Monge-Ortiz et al. 2016), although it is suspected that their inclusion does not resolve the imbalances. The free muscle amino acids measured after feeding do not compose the ideal amino acidic profile compared to fish fed fishmeal diets, at least for gilthead sea bream (Gómez-Requeni et al. 2004). On addition, fish fed plant meal-based diets are known to delay the digestion of those proteins, as evidenced by differences in postprandial enzymatic activity, leading to different rhythms of absorption between synthetic amino acids and digestive amino acids (Santigosa et al. 2008).

Ultimately, if the amino acids absorbed do not meet the amino acidic balance required for protein retention, the excretion of unneeded nitrogen is an unavoidable consequence. The results of the nitrogen balance (Fig. 9) also show that the excreted protein/ingested protein ratio was higher for the VM diet than for the FM diet. Fish fed, the control diet, on the other hand, contain a surplus of protein that is being consistently used for energetic purposes; thus they show a high ammonia excretion regardless of feed intake, while for fish fed VM diet, certain degree of feed intake is necessary for the excretion to take place.

Fish fed to apparent satiation showed the highest ammonia excretion, independently of the consideration of the feed intake in the ratio. Restricted feeding strategies 
(manual feeding and automatic feeding are included in this category) prevent overfeeding and result in less feed wastage and better conversion indexes (Mihelakakis et al. 2002), but, especially for suboptimal diets, fish might increase their ammonia excretion as a result (Kaushik 1998). In contrast, the nutrient efficiency of nonrestricted feeding strategies (auto-demand feeders) is usually higher, as fish are able to regulate their feed intake according to their appetite (Azzaydi et al. 1998). Pedrosa et al. (2019) reported decreased TAN excretion as a result, compared to manual feeding strategies. In our experiment, probably the increased total TAN excretion is caused by the increased feed intake that took place in that stage of the trial, but when feed intake is considered (Fig. 8), the lowest ammonia excretion rate is a reflection of the superior protein efficiency.

Restricted feeding periods have been proven to increase fish metabolism as a result of competition (Cutts et al. 1998), but the observed differences between manual feeding and automatic feeding possibly would require further investigation on a physiological level to determine which one promotes the most competition. The time during which the feed is distributed $\left(\mathrm{g} \mathrm{min}^{-1}\right)$ could be one of the most differentiating aspects, being much quicker for the automatic feeders than were fish are fed by hand. Lastly, it must be noted that even though is well-known that ammonia excretion rate is higher in the early stages of growth, it did not seem to have an influence for our study ( $p$-value $>0.05$ ).

Ammonia removal was also highly dependent on diet and feeding strategy. In the case of restricted feeding strategies, there was a good correlation between the maximum ammonia/mean ammonia concentration and the ammonia removal, which is expected considering the range of ammonia concentration found on the rearing water (Henze et al. 2002). In contrast, in the case of the auto-demand feeders, ammonia removal rates were the highest compared to the remaining feeding strategies, but ammonia concentration in water was not nearly as high, especially for the control diet. Although the spreading of the feeding and the consequent ammonia excretion may explain the absence of notable ammonia peaks, further studies identifying the precise causes of this positive influence in ammonia removal rates are necessary.

On the other hand, for practically every feeding strategy, ammonia removal rates of the systems with fish fed VM diet were lower at similar ammonia excretion. This highlights a negative influence of the plant meal-based diet on the nitrifying capacity. Possibly the poor digestibility of the plant ingredients favored the occurrence of organic matter in water and therefore shifted the $\mathrm{C} / \mathrm{N}$ ratio producing more favorable conditions for the outgrowth of heterotrophic bacteria. Davidson et al. (2013), in a similar study using experimental diets, found no significant differences in ammonia removal rates, and the fishmeal diet only led to a very slightly superior rate (69 vs 71), although the concentration of N-TAN was found to be generally higher in the RAS system for the fish fed plant meal-based diet. Besides, being the influent ammonia concentration higher for the plant diet systems, a superior ammonia removal rate should be expected, since their range of concentrations was optimal for $1 / 2$-order nitrification kinetics $\left(0.58-0.77 \mathrm{mg} \mathrm{L}^{-1}\right)$. In addition, the experimental diets, including the VM diet, were more granular, and therefore they were more prone to partial dilution in water (manifested by the greater saturation of the solid removal systems). This factor might also contribute to the increased organic loading and may indicate an additional source of ammonia (ammonization of the solid particles) not related to ammonia excretion, although this percentage was small and did not reflect itself on the N-TAN concentration levels measured throughout the study. 


\section{Conclusion}

Growth of gilthead sea bream (Sparus aurata) is possible in pilot scale optimized recirculating aquaculture systems with biofilters sized to the predicted ammonia production of fish. Differences in growth were due to the effect of diets.

Oxygen consumption and ammonia excretion were influenced by diet and feeding strategy. Even though the fish growth stage mainly influenced oxygen consumption rates, there still was a significantly greater oxygen consumption rate when diet was distributed by auto-demand feeders, possibly derived from higher feed intake and increased energy use. Ammonia excretion rates were higher with the control diet and the manual feeding strategy. The higher protein content and the unfulfilling energetic and/or balanced protein requirements were most likely responsible for the increased ammonia excretion.

Ammonia removal rates were also dependent on diet and feeding strategy, and only for the restricting feeding periods were proportional to ammonia loading as a consequence of increased excretion. For the auto-demand feeding strategy, ammonia removal was the highest, although the ammonia concentration maximum was not nearly as high as for the other feeding strategies with high removal rates, likely derived from the lack of peaks of ammonia excretion. Differences in diets' organic matter production might lead to differences in ammonia removal rates for fish with similar ammonia excretion, derived by outperformance of heterotrophic bacteria at the expense of nitrifiers.

Funding Open Access funding provided thanks to the CRUE-CSIC agreement with Springer Nature. Research is funded by the national project "Design of a recirculating aquaculture system for aquaculture plants (2011-2014)," by the Ministry of Science and Innovation, Spain, as well as by a grant financed by Generalitat Valenciana, IDIFEDER/2020/029, and by the project "Recirculating aquaculture systems" by Universitat Politècnica de València. The funders had no role in study design, data collection and analysis, decision to publish, or preparation of the manuscript.

Data availability Every data obtained in this study has been presented "as is" on at least one of the figures or tables embedded in the manuscript. Nevertheless, any clarification of the analytical methods from the research (such as calibration parameters) is available from the corresponding author upon reasonable request.

Code availability Not applicable

\section{Declarations}

Ethics approval The experimental protocol implemented in this trial was reviewed and approved by the Committee of Ethics and Animal Welfare of the Universitat Politècnica de València (code: P4-04-05-2017). All experiments were carry out in an accredited animal care facility (code: ES462500001091) in accordance with the Spanish Animal Protection Regulations RD 53/2013, which complies with European Union Directive 2010/63 with regard to the protection of animals used for experimental and other scientific purposes.

Conflict of interest The authors declare no competing interests.

Open Access This article is licensed under a Creative Commons Attribution 4.0 International License, which permits use, sharing, adaptation, distribution and reproduction in any medium or format, as long as you give appropriate credit to the original author(s) and the source, provide a link to the Creative Commons licence, and indicate if changes were made. The images or other third party material in this article 
are included in the article's Creative Commons licence, unless indicated otherwise in a credit line to the material. If material is not included in the article's Creative Commons licence and your intended use is not permitted by statutory regulation or exceeds the permitted use, you will need to obtain permission directly from the copyright holder. To view a copy of this licence, visit http://creativecommons.org/licenses/by/4.0/.

\section{References}

Azzaydi M, Madrid JA, Zamora S et al (1998) Effect of three feeding strategies (automatic, ad libitum demand-feeding and time-restricted demand-feeding) on feeding rhythms and growth in European sea bass (Dicentrarchus labrax L.). Aquaculture 163:285-296. https://doi.org/10.1016/S00448486(98)00238-5

Ballestrazzi R, Lanari D, D'Agaro E, Mion A (1994) The effect of dietary protein level and source on growth, body composition, total ammonia and reactive phosphate excretion of growing sea bass (Dicentrarchus labrax). Aquaculture 127:197-206. https://doi.org/10.1016/0044-8486(94)90426-X

Berge GE, Goodman M, Espe M, Lied E (2004) Intestinal absorption of amino acids in fish: kinetics and interaction of the in vitro uptake of 1-methionine in Atlantic salmon (Salmo salar L.). Aquaculture 229:265-273. https://doi.org/10.1016/S0044-8486(03)00355-7

Bremer Neto H, Graner CAF, Pezzato LE, Padovani CR (2005) Determinação de rotina do crômio em fezes, como marcador biológico, pelo método espectrofotométrico ajustado da 1,5-difenilcarbazida. Ciência Rural 35:691-697. https://doi.org/10.1590/S0103-84782005000300033

Brouwer E (1965) Report of subcommittee on constants and factors energy metabolism. Publ Eur Assoc Anim Prod 11:441-443

Cai Y, Summerfelt RC (1992) Effects of temperature and size on oxygen consumption and ammonia excretion by walleye. Aquaculture 104:127-138. https://doi.org/10.1016/0044-8486(92)90143-9

Cerezo Valverde J, García García B (2004) Influence of body weight and temperature on post-prandial oxygen consumption of common octopus (Octopus vulgaris). Aquaculture 233:599-613. https:// doi.org/10.1016/J.AQUACULTURE.2003.11.025

Cheng ZJ, Hardy RW, Usry JL (2003) Plant protein ingredients with lysine supplementation reduce dietary protein level in rainbow trout (Oncorhynchus mykiss) diets, and reduce ammonia nitrogen and soluble phosphorus excretion. Aquaculture 218:553-565. https://doi.org/10.1016/S0044-8486(02) 00502-1

Cho CY, Kaushik SJ (1990) Nutritional energetics in fish: energy and protein utilization in rainbow trout (Salmo gairdneri). World Rev Nutr Diet 61:132-172. https://doi.org/10.1159/000417529

Colt J (2006) Water quality requirements for reuse systems. Aquac Eng 34:143-156. https://doi.org/10. 1016/j.aquaeng.2005.08.011

Cutts CJ, Metcalfe NB, Taylor AC (1998) Aggression and growth depression in juvenile Atlantic salmon: the consequences of individual variation in standard metabolic rate. J Fish Biol 52:10261037. https://doi.org/10.1006/jfbi.1998.0647

Dalsgaard J, Larsen BK, Pedersen PB (2015) Nitrogen waste from rainbow trout (Oncorhynchus mykiss) with particular focus on urea. Aquac Eng 65:2-9. https://doi.org/10.1016/j.aquaeng.2014.10.004

Dalsgaard J, Pedersen PB (2011) Solid and suspended/dissolved waste (N, P, O) from rainbow trout (Oncorynchus mykiss). Aquaculture 313:92-99. https://doi.org/10.1016/j.aquaculture.2011.01.037

Davidson J, Barrows FT, Kenney PB et al (2016) Effects of feeding a fishmeal-free versus a fishmealbased diet on post-smolt Atlantic salmon Salmo salar performance, water quality, and waste production in recirculation aquaculture systems. Aquac Eng 74:38-51. https://doi.org/10.1016/j.aquae ng.2016.05.004

Davidson J, Good C, Barrows FT et al (2013) Comparing the effects of feeding a grain- or a fish mealbased diet on water quality, waste production, and rainbow trout Oncorhynchus mykiss performance within low exchange water recirculating aquaculture systems. Aquac Eng 52:45-57. https:// doi.org/10.1016/j.aquaeng.2012.08.001

Díaz V, Ibáñez R, Gómez P et al (2012) Kinetics of nitrogen compounds in a commercial marine recirculating aquaculture system. Aquac Eng 50:20-27. https://doi.org/10.1016/j.aquaeng.2012.03.004

Dosdat A, Servais F, Métailler R et al (1996) Comparison of nitrogenous losses in five teleost fish species. Aquaculture 141:107-127. https://doi.org/10.1016/0044-8486(95)01209-5 
Echevarría G, Zarauz N, López-Ruiz J, Zamora S (1993) Study of nitrogen excretion in the gilthead seabream (Sparus aurata 1.): influence of nutritional state. Comp Biochem Physiol Part A Physiol 105:17-19. https://doi.org/10.1016/0300-9629(93)90167-3

Eding EH, Kamstra A, Verreth JAJ et al (2006) Design and operation of nitrifying trickling filters in recirculating aquaculture: a review. Aquac Eng 34:234-260. https://doi.org/10.1016/j.aquaeng.2005.09.007

Engin K, Tufan Eroldoğan O, Özşahinoğlu I et al (2013) Diurnal ammonia and urea excretion rates in European sea bass, Dicentrarchus labrax fed diets containing mixtures of canola and cotton seed oil at two different ambient temperature. J Therm Biol 38:588-596. https://doi.org/10.1016/j.jtherbio. 2013.10.004

Estruch G, Tomás-Vidal A, El Nokrashy AM et al (2018) Inclusion of alternative marine by-products in aquafeeds with different levels of plant-based sources for on-growing gilthead sea bream (Sparus aurata, L.): effects on digestibility, amino acid retention, ammonia excretion and enzyme activity. Arch Anim Nutr 72:321-339. https://doi.org/10.1080/1745039X.2018.1472408

Fagbenro O, Jauncey K (1995) Water stability, nutrient leaching and nutritional properties of moist fermented fish silage diets. Aquac Eng. https://doi.org/10.1016/0144-8609(94)P4432-B

Fernandes P, Pedersen LF, Pedersen PB (2015) Microscreen effects on water quality in replicated recirculating aquaculture systems. Aquac Eng 65:17-26. https://doi.org/10.1016/j.aquaeng.2014.10.007

Foss A, Imsland AK, Roth B et al (2009) Effects of chronic and periodic exposure to ammonia on growth and blood physiology in juvenile turbot (Scophthalmus maximus). Aquaculture 296:45-50. https:// doi.org/10.1016/j.aquaculture.2009.07.013

Francis G, Makkar HP, Becker K (2001) Antinutritional factors present in plant-derived alternate fish feed ingredients and their effects in fish. Aquaculture 199:197-227. https://doi.org/10.1016/S00448486(01)00526-9

García-García BJ, Cerezo Valverde J, Gómez E, Hernández MD, Aguado-Giménez F (2011) Ammonia excretion of octopus (Octopus vulgaris) in relation to body weight and protein intake. Aquaculture 319:162-167. https://doi.org/10.1016/j.aquaculture.2011.06.017

Gallego-Alarcón I, García-Pulido D (2017) Remoción de nitrógeno amoniacal total en un biofiltro: percolador-columna de arena. Tecnol y ciencias del agua 08:81-93. https://doi.org/10. 24850/j-tyca-2017-01-06

Godoy-Olmos S, Martínez-Llorens S, Tomás-Vidal A et al (2019) Influence of temperature, ammonia load and hydraulic loading on the performance of nitrifying trickling filters for recirculating aquaculture systems. J Environ Chem Eng 7:103257. https://doi.org/10.1016/J.JECE.2019.103257

Godoy-Olmos S, Martínez-Llorens S, Tomás-Vidal A, Jover-Cerdá M (2016) Influence of filter medium type, temperature and ammonia production on nitrifying trickling filters performance. J Environ Chem Eng 4:328-340. https://doi.org/10.1016/j.jece.2015.11.023

Gómez-Requeni P, Mingarro M, Calduch-Giner JA et al (2004) Protein growth performance, amino acid utilisation and somatotropic axis responsiveness to fish meal replacement by plant protein sources in gilthead sea bream (Sparus aurata). Aquaculture 232:493-510. https://doi.org/10.1016/S00448486(03)00532-5

Guinea J, Fernandez F (1997) Effect of feeding frequency, feeding level and temperature on energy metabolism in Sparus aurata. Aquaculture 148:125-142. https://doi.org/10.1016/S0044-8486(96) 01424-X

Henze M, Harremoës P, Jansen JLC, Arvin E (2002) Wastewater treatment. Biological and chemical processes, 3rd edn. Springer, Germany

Hoyos JL, Villada HS, Fernández A, Ortega-Toro R (2017) Parámetros de Calidad y Metodologías para Determinar las Propiedades Físicas de Alimentos Extruidos para Peces. Inf Tecnológica 28:101114. https://doi.org/10.4067/s0718-07642017000500012

Kajimura M, Croke SJ, Glover CN, Wood CM (2004) Dogmas and controversies in the handling of nitrogenous wastes: the effect of feeding and fasting on the excretion of ammonia, urea and other nitrogenous waste products in rainbow trout. J Exp Biol 207:1993-2002. https://doi.org/10.1242/ jeb.00901

Kaushik SJ (1998) Nutritional bioenergetics and estimation of waste production in non-salmonids. Aquat Living Resour 11:211-217. https://doi.org/10.1016/S0990-7440(98)89003-7

Kokou F, Fountoulaki E (2018) Aquaculture waste production associated with antinutrient presence in common fish feed plant ingredients. Aquaculture 495:295-310. https://doi.org/10.1016/J.AQUAC ULTURE.2018.06.003

Leung KMY, Chu JCW, Wu RSS (1999) Effects of body weight, water temperature and ration size on ammonia excretion by the areolated grouper (Epinephelus areolatus) and mangrove snapper (Lutjanus argentimaculatus). Aquaculture 170:215-227. https://doi.org/10.1016/S0044-8486(98) 00404-9 
Liao PB, Mayo RD (1972) Salmonid hatchery water reuse systems. Aquaculture 1:317-335. https://doi. org/10.1016/0044-8486(72)90033-6

Lyssenko C, Wheaton F (2006) Impact of rapid impulse operating disturbances on ammonia removal by trickling and submerged-upflow biofilters for intensive recirculating aquaculture. Aquac Eng 35:38-50. https://doi.org/10.1016/j.aquaeng.2005.08.001

Martínez-Llorens S, Baeza-Ariño R, Nogales-Mérida S et al (2012) Carob seed germ meal as a partial substitute in gilthead sea bream (Sparus aurata) diets: amino acid retention, digestibility, gut and liver histology. Aquaculture 338-341:124-133. https://doi.org/10.1016/J.AQUACULTURE.2012. 01.029

Michaud L, Blancheton JP, Bruni V, Piedrahita R (2006) Effect of particulate organic carbon on heterotrophic bacterial populations and nitrification efficiency in biological filters. Aquac Eng 34:224233. https://doi.org/10.1016/j.aquaeng.2005.07.005

Mihelakakis A, Tsolkas C, Yoshimatsu T (2002) Optimization of feeding rate for hatchery-produced juvenile gilthead sea bream (Sparus aurata). J World Aquac Soc 33:169-175. https://doi.org/10. 1111/j.1749-7345.2002.tb00491.x

Miranda KM, Espey MG, Wink DA (2001) A rapid, simple spectrophotometric method for simultaneous detection of nitrate and nitrite. Nitric Oxide 5:62-71. https://doi.org/10.1006/niox.2000.0319

Monge-Ortiz R, Martínez-Llorens S, Márquez L et al (2016) Potential use of high levels of vegetal proteins in diets for market-sized gilthead sea bream (Sparus aurata). Arch Anim Nutr 70:155-172. https://doi. org/10.1080/1745039X.2016.1141743

Monge-Ortiz R, Tomás-Vidal A, Gallardo-Álvarez FJ et al (2018) Partial and total replacement offishmeal by a blend of animal and plant proteins in diets for Seriola dumerili: effects on performance and nutrient efficiency. Aquacult Nutr 24:1163-1174. https://doi.org/10.1111/anu.12655

Morales GA, Azcuy RL, Casaretto ME et al (2018) Effect of different inorganic phosphorus sources on growth performance, digestibility, retention efficiency and discharge of nutrients in rainbow trout (Oncorhynchus mykiss). Aquaculture. https://doi.org/10.1016/j.aquaculture.2018.06.036

Obirikorang KA, Amisah S, Fialor SC, Skov PV (2015) Digestibility and postprandial ammonia excretion in Nile tilapia (Oreochromis niloticus) fed diets containing different oilseed by-products. Aquac Int 23:1249-1260. https://doi.org/10.1007/s10499-015-9881-z

Pedersen LF, Suhr KI, Dalsgaard J et al (2012) Effects of feed loading on nitrogen balances and fish performance in replicated recirculating aquaculture systems. Aquaculture 338-341:237-245. https://doi.org/ 10.1016/j.aquaculture.2012.01.035

Pedrosa RU, Mattos BO, Pereira DSP et al (2019) Effects of feeding strategies on growth, biochemical parameters and waste excretion of juvenile arapaima (Arapaima gigas) raised in recirculating aquaculture systems (RAS). Aquaculture 500:562-568. https://doi.org/10.1016/j.aquaculture.2018.10.058

Piedrahita RH (2003) Reducing the potential environmental impact of tank aquaculture effluents through intensification and recirculation. Aquaculture 226:35-44. https://doi.org/10.1016/S0044-8486(03) 00465-4

Salvetti R, Azzellino A, Canziani R, Bonomo L (2006) Effects of temperature on tertiary nitrification in moving-bed biofilm reactors. Water Res 40:2981-2993. https://doi.org/10.1016/j.watres.2006.05.013

Santigosa E, Sánchez J, Médale F et al (2008) Modifications of digestive enzymes in trout (Oncorhynchus mykiss) and sea bream (Sparus aurata) in response to dietary fish meal replacement by plant protein sources. Aquaculture 282:68-74. https://doi.org/10.1016/J.AQUACULTURE.2008.06.007

Schnetger B, Lehners C (2014) Determination of nitrate plus nitrite in small volume marine water samples using vanadium(III) chloride as a reduction agent. Mar Chem 160:91-98. https://doi.org/10.1016/j. marchem.2014.01.010

Sitjà-Bobadilla A, Peña-Llopis S, Gómez-Requeni P et al (2005) Effect of fish meal replacement by plant protein sources on non-specific defence mechanisms and oxidative stress in gilthead sea bream (Sparus aurata). Aquaculture 249:387-400. https://doi.org/10.1016/J.AQUACULTURE.2005.03.031

Steinarsson A, Moksness E (1996) Oxygen consumption and ammonia excretion of common wolffish Anarhichas lupus (Linnaeus, 1758) in an experimental-scale, seawater, land-based culture system. Aquac Res 27:925-929. https://doi.org/10.1111/j.1365-2109.1996.tb01252.x

von Ahnen M, Pedersen LF, Pedersen PB, Dalsgaard J (2015) Degradation of urea, ammonia and nitrite in moving bed biofilters operated at different feed loadings. Aquac Eng 69:50-59. https://doi.org/10. 1016/j.aquaeng.2015.10.004

Wagner EI, Miller SA, Bosakowski T (1995) Ammonia excretion by rainbow trout over a 24-hour period at two densities during oxygen injection. Progress Fish-Culturist 57:199-205. https://doi.org/10.1577/ 1548-8640(1995)057\%3c0199:AEBRTO\%3e2.3.CO;2 
Wood CM (2001) Influence of feeding, exercise and temperature on nitrogen metabolism and excretion. Fish Physiology Volume 20: On Nitrogen Excretion. Academic Press, London, pp 201-238

Wu X, Gatlin DM (2014) Effects of altering dietary protein content in morning and evening feedings on growth and ammonia excretion of red drum (Sciaenops ocellatus). Aquaculture 434:33-37. https://doi. org/10.1016/j.aquaculture.2014.07.019

Zhu S, Chen S (1999) An experimental study on nitrification biofilm performances using a series reactor system. Aquac Eng 20:245-259. https://doi.org/10.1016/S0144-8609(99)00019-9

Zhu S, Chen S (2001) Effects of organic carbon on nitrification rate in fixed fillm biofilters. Aquac Eng 25:221-237. https://doi.org/10.1016/S0144-8609(01)00071-1

Publisher's note Springer Nature remains neutral with regard to jurisdictional claims in published maps and institutional affiliations. 